\section{An Attempt to obtain Auto-immunity to Tumours with Freund's Adjuvant and Tetanus Toxoid}

Since Freund first showed that a demyelinating encephalitis could be produced by the subcutaneous injection of brain tissue with an adjuvant prepared from tubercle bacilli, this method has been used to induce other auto-antibodies. Freund and other workers have shown aspermatogenesis following the injection of homologous testicular extract with an adjuvant $^{1}$, and similarly other auto-antibodies have been produced against lens tissue ${ }^{2}$ and peripheral nerves ${ }^{3}$.

It seemed feasible, therefore, that auto-antibodies might be induced against growing tumour tissue by the injection of homologous tumour extracts with an adjuvant, and that if such a reaction were produced, retardation or even destruction of the tumour might follow. The following experiments were therefore undertaken to see if this were so, using a $C+$ strain of mice of the same age and with spontaneous tumours of the same size.

The adjuvant was prepared by mixing 0.025 per cent killed, dried, Mycobacterium butyricum with 85 per cent thin mineral oil and 15 per cent 'Arlacel $A$ ', the mixture being sterilized by autoclaving.

At the beginning of these experiments, pulped tumour was used, but this was difficult to inject with a syringe, and since reading Graham and Graham's paper ${ }^{4}$, their method of passing tumour tissue through a fine, stainless steel sieve, with 250 pores to the inch, has been followed. The resultant paste was then scraped from the under surface of the sieve, using an aseptic technique, and mixed with equal portions of adjuvant and 1/2,240 of a human dose of tetanus toxoid. The latter was added both as an additional stimulus to the reticuloendothelial system and to prevent the mice from developing tetanus, a disease to which they are susceptible.

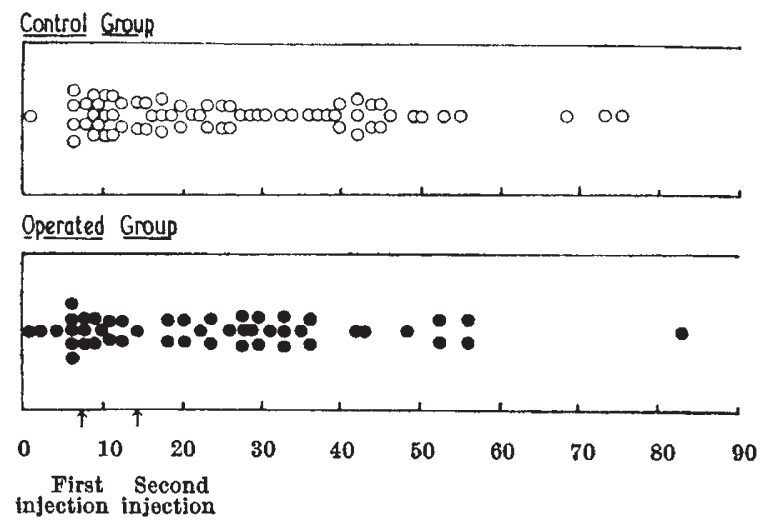

injection injection

Survival after operation (days)

Fig. 1

Portions of tumours were removed under ether anæsthesia from 48 mice of the same spontaneous tumour-bearing strain, of the same age and with tumours of the same size. The tumour tissue was then passed through a sieve and re-injected subcutaneously with Freund's adjuvant and tetanus toxoid into the mouse from which it was obtained. Roughly twothirds of this material was kept in a labelled container at $4^{\circ} \mathrm{C}$. and the same mouse re-injected with this a week later and again two weeks later. The mice were identified by the number of slits made in their ears for this purpose. Sixty-six mice with tumours of similar size, of the same strain and the same age, were used as controls, and the subsequent life-span of the two groups compared.

No significant difference in the life-span of the two groups was found. The tumours in the operated mice continued to grow, and secondary tumours seemed to develop as readily as in the control mice. No clinical evidence of auto-immunity could be obtained of tumours when portions of these were injected on three separate occasions with Freund's adjuvant and tetanus toxoid.

This investigation was made possible by a grant from the Endowment Fund of the Royal Free Hospital, London, and by a supply of tumour mice from the Chester Beatty Cancer Research Institute, London.

\section{E. L. RHODES *}

100, Green Lane, Hersham,

Walton on Thames, Surrey.

* Present address: Department of Dermatology, Denmark Hill London, S.E.5.

${ }^{1}$ Freund, J., Lipton, M. M., and Thompson, G. E., J. Exp. Med., 101, 591 (1955).

"Halbert, S. P., Locather-Khorazo, D., Swick, L., Witmer, R., Seegal, B., and Fitzgerald, P., J. Exp. Med, 105, 439 (1957).

${ }^{3}$ Waksman, B. H., and Adams, R. D., J. Exp. Med., 102, 213 (1955).

- Graham, J., and Graham, R., Surg. Gynocol. and Obst. (August 1859).

\section{$\beta_{2 A^{-}}$Globulin as a Possible Carrier of Allergic Reaginic Activity}

REaGins of the hay-fever type have never been clearly identified with either of the two serum protein fractions usually associated with antibody activity, namely, $\gamma$-globulin $(7 S \gamma)$ and $\beta_{2} M$-globulin $(19 S \gamma)$. It is known, however, that there exists a third serum protein, which is immunologically and functionally related to $\gamma$-globulin ${ }^{1}$, and which is also a carrier of antibody activity ${ }^{2}$. This third component is $\beta_{2 A^{*}}$ globulin, which was first isolated and described by one of us $^{3}$. Though the presence of $\beta_{2 A}$-globulin in reaginic fractions has been suggested ${ }^{4}$, and its possible role in allergic phenomena considered ${ }^{5}$, positive evidence has never been brought forward that $\beta_{2 A}$. globulin might be the essential carrier of reaginic activity. This may be due to the fact that all skinsensitizing preparations so far obtained contained appreciable amounts of $\gamma$-globulin.

The methods at present available for the isolation of immunologically pure $\beta_{2 A}$-globulin ${ }^{1}$ are not suitable for small individual serum samples, and therefore the following simplified procedure was developed in order to obtain a serum fraction essentially devoid of $\beta_{2} M^{-}$and $\gamma$-globulins, but still containing many $\beta_{2 A}$-globulins.

To $8 \mathrm{ml}$. of the serum samples were added $8 \mathrm{ml}$. of $0 \cdot 1 M$ zinc sulphate. The mixture was shaken thoroughly and enough sodium carbonate was added (usually $0.065 \mathrm{ml}$. of a 10 per cent aqueous solution) to raise the $p H$ to $6.9 \pm 0.05$. After standing for $1 \mathrm{hr}$. at room temperature $\left(25^{\circ}\right.$ C. $)$, the mixture was filtered through a layer of Whatman No. 1 paper. The filtrate was freed from zinc by addition of 60 mgm. of trisodium ethylenediamine tetraacetate and subsequent overnight dialysis against 200 volumes of cold saline. The fractions were then concentrated to about $0.8 \mathrm{ml}$. by dialysis against concentrated 'Carbo- 